\title{
Postharvest \\ Performance of Southern Highbush Blueberry Fruit
}

Gregory A. Lang and

Jiaxun Tao

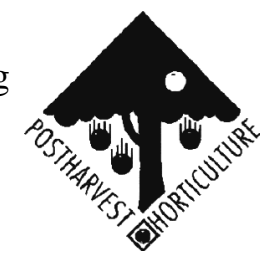

Additional index words. Vaccinium spp. hybrids, early market, fruit quality, storage life, shelf life

Summary. The postharvest performance of early ripening southern highbush blueberries 'Sharpblue' and 'Gulfcoast' was evaluated under storage and simulated retail conditions. In general, 'Gulfcoast' fruit were 28\% heavier than those of 'Sharpblue', which had a higher percent soluble solids concentration (SSC) and lower titratable acidity (TA). Quality loss, as indexed by fresh weight, percent decayed fruit, or changes in SSC, $\mathrm{pH}$, or TA, was insignificant in first-harvest fruit of either cultivar when kept in storage (2C) for up to 7 days. Transfer of fruit stored at $2 \mathrm{C}$ for 3 days to simulated retail conditions at $21 \mathrm{C}$ for 4 days significantly increased fresh weight loss and decay, but not beyond levels deemed unmarketable.

Second-harvest fruit were smaller than first-harvest fruit, and those of 'Sharpblue' fruit were more prone to decay. However, storage quality of both cultivars was acceptable through 11 days at 2C. Retail quality, as influenced by decay incidence, was acceptable after 3 days at $2 \mathrm{C}$ plus 4 days at $21 \mathrm{C}$, but not after 3 days at $2 \mathrm{C}$ plus 8 days at 21C. Overall, fruits of these early ripening southern highbush blueberry cultivars performed well under postharvest conditions and are suitable for expanding production of premium fresh blueberries by growers in the Gulf coastal plains.

$\overline{\text { Department of Horticulture, Louisiana Agricultural }}$ Experiment Station, Louisiana State University Agricultural Center, Baton Rouge, LA 70803.

Approved for publication by the Director of the Louisiana Agricultural Experiment Station as manuscript no. 91-28-5397. We thank A.M. Saxton for statistical advice and N.S. Lang, D.H. Picha, and E.E. Puls for their critical reviews of the manuscript. 
$\mathrm{S}$ outhern highbush blueberries [hybrids of Vaccinium corymbosum L. with V. darrowi Camp and V. ashei Reade (Lyrene, 1990)] have been selected for low chilling requirements and short fruit-development periods. These traits provide growers of rabbiteye blueberries with the potential to achieve a longer marketing window and higher fresh-market prices, based on domestic and international market trends for early fruits (Lang and Danka, 1991a). Commercial low-chill southern highbush production originated in Florida (Lyrene and Sherman, 1984) during the mid1980s with 'Sharpblue'. Rapid expansion of production is expected during the 1990s due to recent releases of new cultivars adapted to the Gulfstates from Texas to North Carolina (e.g., Ballington et al., 1990a, 1990b; Krewer, 1987).

There is potential for early market blueberries in the most southern U.S. production areas, beginning with central Florida and continuing north along the coastal plains to the Carolinas and west to southeast Texas. Low-chilling-requirement highbush blueberries selected for these areas include the following cultivars. 'Avonblue', 'Flordablue', and 'Sharpblue' were released in the mid-1970s (Sharpe and Sherman, 1976a, 1976b; Sherman and Sharpe, 1977); the former two have performed relatively poorly since release, while the latter has become the early ripening industry standard. 'Marimba' and 'Misty' are recent releases that have not been widely tested (Sherman and Lyrene, 1991). 'Gulfcoast' was released in the mid-1980s (Krewer, 1987) and has shown promise for good plant vigor, large fruit, and relative self-fruitfulness (Lang and Danka, 1991a, 1991b) compared with 'Sharpblue'. 'Gulfcoast', 'Cooper', 'Georgiagem', and 'O'Neal' also appear to be suited to the rest of the Gulf coastal plains production regions.

Fruit quality and performance under storage or retail conditions are important considerations in cultivar selection for high value, premium freshmarket fruits. Shelf life (Ballinger et al., 1978) and susceptibility to decay (Ballinger, 1983) differ among northern highbush blueberry cultivars. This study characterizes fruit quality of 'Sharpblue' and 'Gulfcoast' southern highbush blueberries at harvest, as well as during storage and simulated retail conditions.

\section{Materials and Methods}

Fruit harvest and postharvest treatments. Commercially ripe fruit of 'Sharpblue' and 'Gulfcoast' were hand-harvested on 6-7 May ( first harvest) and 12-13 May (second harvest) from 4-year-old plants on raised beds at the Louisiana State Univ. Horticulture Farm in Baton Rouge, La. Harvested fruits were precooled to $2 \mathrm{C}$ (Cappellini et al., 1983).

Fruits $(\approx 150 \mathrm{~g})$ from the first harvest were placed randomly in plastic mesh half-pint (225-ml) containers lined with six layers of paper tissue and covered with clear polyethylene plastic wrap kept in place by a rubber band. Storage temperature was 2C. Stored samples were removed after 0 , 3 , 5, and 7 days and evaluated for percent weight loss, percent decayed or moldy berries, soluble solids concentration (SSC), $\mathrm{pH}$, and titratable acidity (TA).

After 3 days, some samples were transferred from 2 to $21 \mathrm{C}$ to simulate retail conditions (Ceponis and Cappellini, 1985). Fruits were evaluated after two or four additional days. There were three replications of single half-pint lots for each sampling.

The experiment was repeated with fruits from the second harvest period. The periods of storage for the second experiment were $0,7,11$, and 15 days at $2 \mathrm{C}$ and 3 days at $2 \mathrm{C}$ plus 4,8 , and 12 days at $21 \mathrm{C}$.

Fruit analyses. Fruit samples were weighed before treatment and at sampling to determine percent fresh weight loss. At sampling, all berries (except those with substantial decay) were frozen for analysis of SSC, $\mathrm{pH}$, and TA. At least $30 \mathrm{~g} / \mathrm{sample}$ was homogenized with a mortar and pestle, then centrifuged at $3000 \times g$ for $15 \mathrm{~min}$. The $\mathrm{pH}$ of the supernatant was determined with a $\mathrm{pH}$ meter (Orion SA-520, American Scientific Products, McGaw Park, Ill.). Percent SSC was determined with a hand-held refractometer (Atago N-20, Tokyo), and TA was titrated with $0.1 \mathrm{~N} \mathrm{NaOH}$ using $\mathrm{pH}$ 8.1 as the endpoint and expressed as milligrams citric acid per $100 \mathrm{ml}$.

Data were analyzed by analysis of variance, and mean separations were performed by Duncan's multiple range test (SAS, 1985).

\section{Results}

Fruit quality at harvest. As a subjective observation of quality, 'Gulfcoast' fruits were lighter blue (indicating a more desirable waxy "bloom") than 'Sharpblue'. On average, 'Gulfcoast' fruits were $28 \%$ heavier and 9\% larger (Table 1), as well as 14\% firmer (data not shown) than 'Sharpblue' fruits at harvest. Consequently, half-pint packs of 'Gulfcoast' blueberries held $\approx 25$ fewer fruits than did packs of 'Sharpblue'. 'Sharpblue' fruits had consistently higher SSC and $\mathrm{pH}$ and lower TA (Table 1) which resulted in an average SSC : TA ratio 51\% higher than for 'Gulfcoast' fruits. Using the classification criteria of Galletta et al. (1971), 'Gulfcoast' fruit had low to medium acidity and medium to high SSC, while 'Sharpblue' fruit had low acidity and high SSC. From these values, the data of Galletta et al. predict that both cultivars may resist decay fairly well under retail conditions for at least 7 to 10 days.

Fruit diameter, weight, and SSC decreased $\approx 9 \%$ from the first to the second harvest for both cultivars (Table 1). Titratable acidity and $\mathrm{pH}$ were not affected by harvest date.

Table 1. Fruit size, soluble solids concentration (SSC), pH, titratable acidity (TA), and soluble solids : acidity ratio (SSC : TA) for 'Gulfcoast' (GC) and 'Sharpblue' (SB) southern highbush blueberry fruits. Cultivar data are for pooled harvests; harvest date data are for pooled cultivars.

\begin{tabular}{lccccc}
\hline & \multicolumn{2}{c}{ Cultivar $^{2}$} & & \multicolumn{2}{c}{ Harvest date } \\
\cline { 2 - 3 } Quality characteristic & GC & SB & & 6-7 May & 12-13 May \\
\hline \hline Fruit diam $(\mathrm{mm})$ & $15.9 \mathrm{a}$ & $14.6 \mathrm{~b}$ & & $15.9 \mathrm{a}$ & $14.6 \mathrm{~b}$ \\
Fruit wt $(\mathrm{g})$ & $1.70 \mathrm{a}$ & $1.33 \mathrm{~b}$ & $1.58 \mathrm{a}$ & $1.44 \mathrm{~b}$ \\
SSC $(\%)$ & $10.7 \mathrm{a}$ & $11.6 \mathrm{~b}$ & & $11.6 \mathrm{a}$ & $10.7 \mathrm{~b}$ \\
pH & $2.9 \mathrm{a}$ & $3.1 \mathrm{~b}$ & & $3.0 \mathrm{a}$ & $3.0 \mathrm{a}$ \\
TA & $124 \mathrm{a}$ & $89 \mathrm{~b}$ & & $105 \mathrm{a}$ & $108 \mathrm{a}$ \\
SSC $:$ TA & $8.6 \mathrm{a}$ & $13.0 \mathrm{~b}$ & & $11.0 \mathrm{a}$ & $9.9 \mathrm{~b}$ \\
\hline
\end{tabular}

${ }^{7}$ Within-row numbersfollowed by the same letters are not significantly different at $P=0.05$.

${ }^{y}$ Expressed as milligrams citric acid/100 ml. 
'Gulfcoast' fruit in storage. First-harvest fruit stored at $2 \mathrm{C}$ continuously or for 3 days followed by 4 days at $21 \mathrm{C}$ showed only a significant change in fresh weight, although losses never exceeded 3\% (Table 2). Fruit decay was low $(<2 \%)$ at $2 \mathrm{C}$ and increased only slightly to $4.1 \%$ after four additional days at $21 \mathrm{C}$. This level of decay after 4 days of simulated retail storage is well within commercially acceptable levels. Titratable acidity, percent SSC, and $\mathrm{pH}$ did not change significantly.

Second-harvest fruit also exhibited little change in percent decay, percent SSC, $\mathrm{pH}$, or TA and only a small loss of fresh weight during 15 days of storage at $2 \mathrm{C}$ (Table 2). Likewise, quality of fruit transferred to $21 \mathrm{C}$ for 4 days was similar to that of fruit stored for 11 days at 2C. Only fruit transferred to $21 \mathrm{C}$ for 8 days changed substantially, including significantly lower TA and SSC, increased fresh weight loss, and excessive fruit decay. Continuing storage at $21 \mathrm{C}$ through 12 days resulted in greatly accelerated decay, fresh weight loss, and increased $\mathrm{pH}$, as well as accelerated decreases in SSC and TA (data not shown). Because the maximum storage plus retail period for premium early market fruit is $\leq 1$ week, the postharvest quality of both first- and second-harvest 'Gulfcoast' fruit probably would be more than adequate for the premium early market.
'Sharpblue' fruit in storage. Like 'Gulfcoast', there were significant, but only minor, changes in first-harvest fruit quality components over the 7day postharvest period, regardless of whether fruit were stored at $2 \mathrm{C}$ continuously or for 3 days followed by 4 days at 21C (Table 3). Fresh weight loss and fruit decay increased only slightly after transfer to 21C. Unlike 'Gulfcoast', however, percent SSC decreased significantly during storage. The changes in TA during storage were variable, and $\mathrm{pH}$ did not change.

For second-harvest fruits stored at $2 \mathrm{C}$, the only major changes were significant increases in fresh weight loss and fruit decay that did not exceed unacceptable levels (i.e., 20\%; Ballinger et al., 1978) even after 15 days. At 2C, percent SSC, $\mathrm{pH}$, and TA did not change significantly. At $21 \mathrm{C}$, fresh weight loss and fruit decay increased significantly, becoming unacceptable after 8 days. Overall, second-harvest 'Sharpblue' fruit was more prone to weight loss and decay at $21 \mathrm{C}$ than first harvest fruit. Fruits transferred to $21 \mathrm{C}$ for 8 days also exhibited a significant $20 \%$ loss in titratable acidity.

\section{Discussion}

'Gulfcoast' and 'Sharpblue' southern highbush blueberries performed well under postharvest storage plus retail conditions for at least 7 days, exceeding the performance of northern highbush fruit in some other studies (Ceponis and Cappellini, 1985). In comparing the cultivars, 'Gulfcoast' fruits were larger, firmer, and performed better under extended storage conditions, while 'Sharpblue' fruits were higher in SSC and $\mathrm{pH}$ and lower in TA. The better performance of 'Gulfcoast' during longer storage conditions may be a function of its significantly $(\approx 40 \%)$ higher TA and its consistently lower $(\approx 50 \%)$ SSC : TA ratio (Ballinger and Kushman, 1970; Galletta et al., 1971). Fruit firmness loss did not appear to be a major quality variable affecting fruit storage and shelf life from these early market cultivars.

The quality characteristic most sensitive to postharvest temperature was decay induced by fungal organisms, although levels remained within commercial limits through 7 days of storage or storage plus retail conditions for both cultivars. The primary site of infection was at the stem-end scar, as has been noted for northern highbush blueberries (Cappellini and Ceponis, 1977), and the predominant fungi appeared to be Colletotrichum spp. anthracnose and Botrytis spp. mold (unconfirmed observation). Cappellini et al. (1982) reported that the primary fungus responsible for decay in early harvested northern highbush fruit in

Table 2. Postharvest fruit quality characteristics for 'Gulfcoast' blueberry fruits stored at $2 \mathrm{C}$ and transferred to $21 C$.

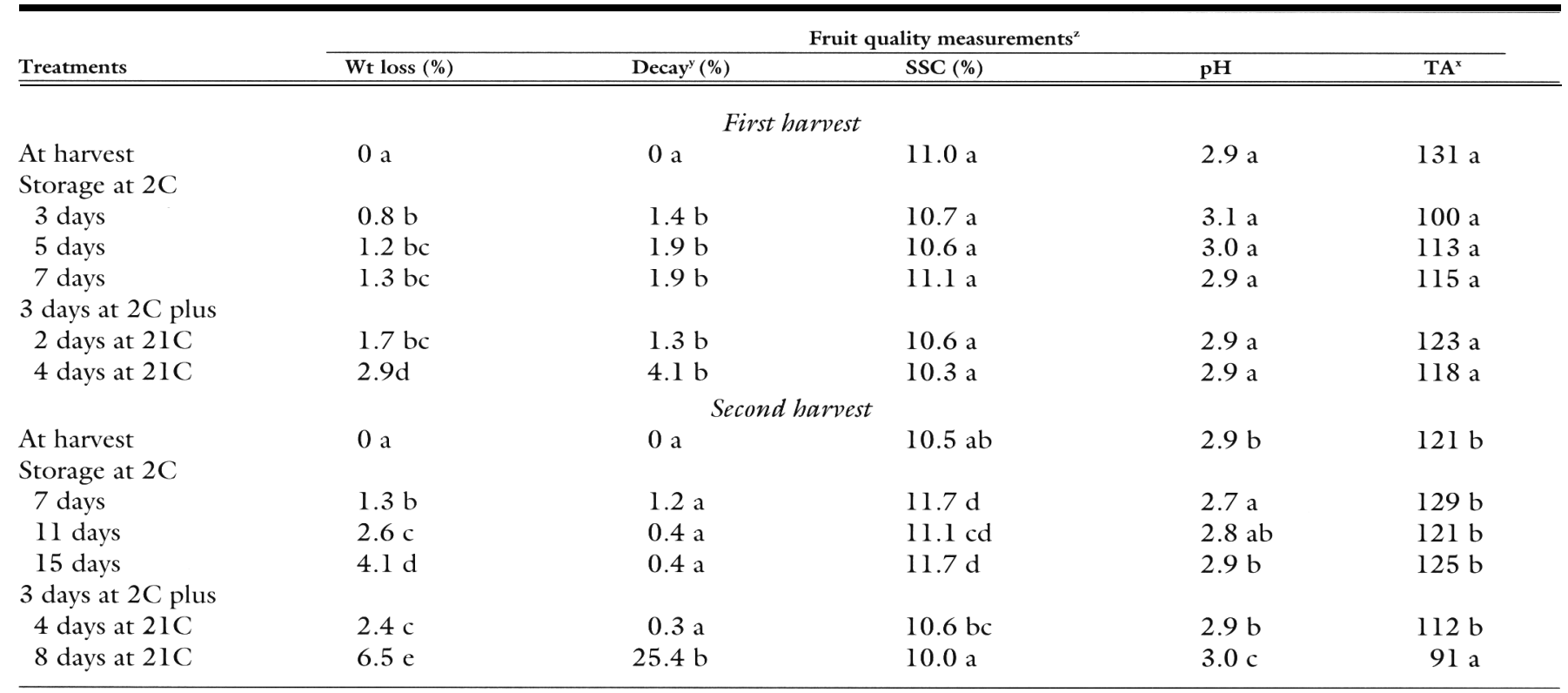

${ }^{2}$ Numbers under same columns within the same harvest date followedby same letters are not significantly different at $P=0.05, \quad$ Duncan's multiple range test. 'Percent decay $=$ (no. fruits with fungal growth)/(total no. fruits).

${ }^{x}$ Expressed as milligrams citric acid/100 $\mathrm{ml}$. 


\begin{tabular}{|c|c|c|c|c|c|}
\hline \multirow[b]{2}{*}{ Treatments } & \multicolumn{5}{|c|}{ Fruit quality measurements ${ }^{2}$} \\
\hline & Wt loss (\%) & Decay $^{y}(\%)$ & SSC (\%) & $\mathrm{pH}$ & $\mathrm{TA}^{\mathrm{x}}$ \\
\hline \multicolumn{6}{|c|}{ First harvest } \\
\hline At harvest & $0 \mathrm{a}$ & $0 \mathrm{a}$ & $12.4 \mathrm{c}$ & $3.1 \mathrm{a}$ & $84 \mathrm{ab}$ \\
\hline \multicolumn{6}{|l|}{ Storage at $2 \mathrm{C}$} \\
\hline 3 days & $0.9 \mathrm{~b}$ & $2.7 \mathrm{bc}$ & $12.1 \mathrm{bc}$ & $3.1 \mathrm{a}$ & $80 \mathrm{a}$ \\
\hline 5 days & $1.1 \mathrm{~b}$ & $1.6 \mathrm{~b}$ & $11.5 \mathrm{ab}$ & $3.0 \mathrm{a}$ & $99 \mathrm{c}$ \\
\hline 7 days & $1.5 \mathrm{c}$ & $2.0 \mathrm{~b}$ & $11.4 \mathrm{a}$ & $3.0 \mathrm{a}$ & $95 \mathrm{bc}$ \\
\hline \multicolumn{6}{|l|}{3 days at $2 \mathrm{C}$ plus } \\
\hline 2 days at $21 \mathrm{C}$ & $1.8 \mathrm{c}$ & $3.0 \mathrm{~b}$ & $11.5 \mathrm{ab}$ & $3.0 \mathrm{a}$ & $88 \mathrm{abc}$ \\
\hline 4 days at $21 \mathrm{C}$ & $3.0 \mathrm{~d}$ & $3.7 \mathrm{c}$ & $11.1 \mathrm{a}$ & $3.0 \mathrm{a}$ & $87 \mathrm{abc}$ \\
\hline \multicolumn{6}{|c|}{ Second harvest } \\
\hline At harvest & $0 \mathrm{a}$ & $0 \mathrm{a}$ & $10.9 \mathrm{a}$ & $3.1 \mathrm{a}$ & $94 \mathrm{~b}$ \\
\hline \multicolumn{6}{|l|}{ Storage at $2 \mathrm{C}$} \\
\hline 7 days & $2.0 \mathrm{ab}$ & $3.4 \mathrm{ab}$ & $11.6 \mathrm{a}$ & $3.1 \mathrm{ab}$ & $90 \mathrm{~b}$ \\
\hline 11 days & $3.5 \mathrm{bc}$ & $7.0 \mathrm{abc}$ & $11.0 \mathrm{a}$ & $3.1 \mathrm{ab}$ & $92 \mathrm{~b}$ \\
\hline 15 days & $6.2 \mathrm{~d}$ & $9.3 \mathrm{bc}$ & $11.7 \mathrm{a}$ & $3.1 \mathrm{ab}$ & $86 \mathrm{ab}$ \\
\hline \multicolumn{6}{|l|}{3 days at $2 \mathrm{C}$ plus } \\
\hline 4 days at $21 \mathrm{C}$ & $4.9 \mathrm{~cd}$ & $12.0 \mathrm{c}$ & $11.6 \mathrm{a}$ & $3.2 \mathrm{ab}$ & $81 \mathrm{ab}$ \\
\hline 8 days at $21 \mathrm{C}$ & $8.9 \mathrm{e}$ & $36.9 \mathrm{~d}$ & $11.5 \mathrm{a}$ & $3.2 \mathrm{~b}$ & $75 \mathrm{a}$ \\
\hline
\end{tabular}

${ }^{\overline{2}}$ Numbers under same columns within the same harvest date followed by same letters are not significantly different at $P=0.05$, Duncan's multiple range test. ${ }^{y}$ Percent decay $=$ (no. fruits with fungal growth $) /($ total no. fruits $)$.

${ }^{x}$ Expressed as milligrams citric acid/100 ml.

New Jersey was gray mold (Botrytis cinerea Pers. ex Fr.).

Low storage temperature (2C) greatly retarded fruit decay compared with moderate retail temperature (21C), as has been noted by others (Ballinger et al., 1978; Ceponis and Cappellini, 1985). The rate of decay in either southern highbush cultivar at $2 \mathrm{C}$ was much slower than that reported for northern highbush fruit (Ceponis and Cappellini, 1983). This may be due to inherently low levels of fungal inoculum during the earliest harvests, since Cappellini et al. (1982) found that early harvested blueberry fruit from various regions had about half the quality defects of late-harvested fruit.

Consequently, fruit from these southern highbush blueberry cultivars maintained the excellent quality required for premium early markets, provided fruits were cooled initially and stored at low temperatures and that exposure to retail conditions (moderate temperatures) was limited to $\approx 4$ days. Early market fruit such as these may actually maintain higher postharvest quality than later-ripening fruit, since populations of fungal decay organisms are probably lower during early harvests. Although 'Gulfcoast' had better initial and extended postharvest fruit quality than the current industry standard, 'Sharpblue', a caveat must be noted for its future production.
Both cultivars exhibited some degree of undesirable pedicel adherence to the fruit or tearing at the stem scar, but 'Gulfcoast' had a consistently higher incidence (data not shown, but observation confirmed by several blueberry researchers in the Southeast). Slower picking techniques, more time spent grading fruit, and/or further research on potential modification ofproduction practices may be required to reduce the incidence of adhering pedicels.

\section{Literature Cited}

Ballinger, W.E. 1983. Postharvest decay of blueberries as influenced by water dips and captafol. J. Amer. Soc. Hort. Sci. 108:422424.

Ballinger, W.E. and L.J. Kushman. 1970. Relationship of stage of ripeness to composition and keeping quality of highbush blueberries. J. Amer. Soc. Hort. Sci. 95:239-242.

Ballinger, W.E., E.P. Maness, and W.F. McClure. 1978. Relationship of stage of ripeness and holding temperature to decay development of blueberries. J. Amer. Soc. Hort. Sci. 103:130-134.

Ballington, J.R., C.M. Mainland, S.D. Duke, A.D. Draper, and G.J. Galletta. 1990a. 'O'Neal' southern highbush blueberry. HortScience 25:711-712.

Ballington, J.R., C.M. Mainland, S.D. Kooks, A.D. Draper, and G.J. Galletta. 1990b. 'Blue Ridge' and 'Cape Fear' southern highbush blueberries. HortScience 25:1668-1670.

Cappellini, R.A. and M.J. Ceponis. 1977. Vulnerability of stem-end scars of blueberry fruits to postharvest decays. Phytopathology 67:118-119.

Cappellini, R.A., M.J. Ceponis, and G. Koslow. 1982. Nature and extent of losses in consumer-grade samples of blueberries in greater New York. HortScience 17:55-56.

Cappellini, R.A., M.J. Ceponis, and C.P. Schulze, Jr. 1983. The influence of "sweating" on postharvest decay of blueberries. Plant Dis. 67:381-382.

Ceponis, M.J. and R.A. Cappellini. 1983. Control of postharvest decays of blueberries by carbon dioxide-enriched atmospheres. Plant Dis. 67:169-171.

Ceponis, M.J. and R.A. Cappellini. 1985. Reducing decay in fresh blueberries with controlled atmospheres. HortScience 20:228-229.

Galletta, G. J., W.E. Ballinger, R. J. Monroe, and L.J. Kushman. 1971. Relationship between fruit acidity and soluble solids levels of highbush blueberry clones and fruit keeping quality. J. Amer. Soc. Hort. Sci. 96:758-762.

Krewer, G. W. 1987 The blueberry beat. Fruit South 8(2):22-23.

Lang, G.A. and R. G. Danka. 1991a. Honey bee-mediated cross- vs. self-pollination of 'Sharpblue' blueberry affects fruit development period and fruit size. J. Amer. Soc. Hort. Sci. 116:770-773. 
Lang, G.A. and R.G. Danka. 1991b. The influence of self- and cross-pollination on fruiting in southern highbush blueberries. HortScience 26:486. (Abstr.)

Lyrene, P.M. 1990. Low-chill highbush blueberries. Fruit Var. J. 44:82-86.

Lyrene, P.M. and W.B. Sherman. 1984.

Breeding early-ripening blueberries for Florida. Proc. Fla. State Hort. Soc. 97:322325 .

SAS. 1985. SAS user's guide: Statistics, version. 5th ed. SAS Institute, Inc., Cary, N.C.

Sharpe, R.H. and W.B. Sherman. 1976a. 'Flordablue' blueberry. HortScience 11:64-65.

Sharpe, R.H. and W.B. Sherman. $1976 b$. 'Sharpblue' blueberry. HortScience 11:65.

Sherman, W.B. and P.M. Lyrene. 1991. Deciduous fruit cultivar development in Florida. HortScience 26:2,91.

Sherman, W.B. and R.H. Sharpe. 1977.

'Avonblue' blueberry. HortScience 12:510. 